\title{
Crime Investigation of Trade of The Human Body Organs on Criminal Investigation Police (Case Study Police Report Number: LP / 43 / I / 2016 / Bareskrim dated 13 January 2016)
}

\author{
Yeremias Tony Putrawan ${ }^{1}$, Jawade Hafiz ${ }^{2}$ and Aryani Witasari ${ }^{3}$
}

Abstract. The purpose of this research know and analyze doubt enforcing the investigation of criminal trafficking of human organs carried out by the Criminal Investigation Police, to determine the factors that affect the implementation of the investigation of criminal trafficking of human organs carried out by the Criminal Investigation Police, to know the efforts the police in tackling the trade in human organs and factors inhibiting the Police in tackling trafficking in human organs.

The method used is the method of normative and juridical sociologic, the specifications in the study was a descriptive analytical methods of population and sampling are all objects or all of the symptoms or the entire event or the entire unit to be studied, data collection techniques using literature study and interviews, data analysis is qualitative.

Result: Implementation of the investigation of criminal trafficking of human organs in accordance with the Regulation no. 14 Of 2012 on Management Investigations. In the process, the investigator did not experience any problems in the arrest of the perpetrators, because in the process of investigation the investigator obtain complete information from the victim as well as by using techniques evident triangle obtained further evidence used to ensnare offenders. The factors that affect the implementation of the criminal investigation of organ trafficking the human body that carried out by the Police Criminal Investigation divided into two: a supporting factor comes from: the power of law enforcement officers who have sufficient personnel and high professionalism, Police efforts to combat trafficking in organs, namely prevention, eradication and prevention of the crime of trafficking of human organs by running strategy repressive functions, namely in the form of punishment with the most severe penalties. Factors inhibiting factor is the legal, law enforcement, means infrastructures, society and culture

Key words: Investigation; Crime; Trafficking; Human Organs.

\section{Introduction}

Trafficking in persons (human trafficking) that operates in secret and move outside the law. Traffickers who quickly developed into cross-border syndication with caution in ensnare his victims, but very quick to exploit it in various ways so that the victim was powerless to free themselves. Trafficking in persons and or known as human trafficking emerging lately become a matter of much debate both on the regional and global level.

The criminal acts of trafficking in persons is an act of recruitment, transportation,

\footnotetext{
${ }^{1}$ Student of Master of Law, Universitas Islam Sultan Agung Semarang and Indonesia Police member, Email: yeremias.2006.71@gmail.com

${ }^{2}$ Lecturer of Master of Law, Sultan Agung Islamic University (UNISSULA), Semarang

${ }^{3}$ Lecturer of Master of Law, Sultan Agung Islamic University (UNISSULA), Semarang
} 
storage, transportation, transfer or receipt of persons by threat of violence, use of force, abduction, confinement, fraud, deception, abuse of power or vulnerability, debt bondage or giving payments or benefits, so as to obtain approval of a person having control over another person, whether committed in the country and between countries, for the purpose of sexual trafficking and sexual exploitation, migrant workers, legal and illegal, adoption, orders, domestic workers, beggars, industry pornography, trafficking drugs, the sale of organs, other forms of exploitation. ${ }^{1}$

The practice of organ trafficking has become a lucrative and promising prospect given the benefits that can be obtained from an organ trade. In the midst of economic pressure that is felt today's society, the organ trade has become a lucrative land to earn money and profit. Organ trade usually begins with ads or offers, from patients and their families. Usually through newspapers or the Internet in the form of donor search by number to contact if there is interest. Other shapes that offer comes from the prospective donors are willing to give their organs to the needy with certain benefits. To fool in order to avoid the snares of the law then usually operandy mode by creating a fake identity card as if the donor is a sibling of the patient. In addition it can offer comes from people who intend to sell their organs in order to earn some money. ${ }^{2}$ Vulnerable victims become targets of human organs trafficking cases are children and people who have low knowledge and experience economic pressure has the potential to become a victim of human organs trafficking cases this. In the opinion of Riyadi and Bahaweres (2011), an area prone to cases of trafficking in human organs is Tangerang, Indonesian workers in Taiwan and Malaysia, and Australia. In 2015, cases of organ trafficking were successfully solved by the Police Criminal Investigation is a case of human organ trafficking in West Java. Area prone to occur in human organs trafficking are diverse, especially in villages and remote areas. ${ }^{3}$

Case sticking out of the crime of trafficking in human organs in Indonesia, and the first to successfully dealt with by the Police was the case in 2015 with the discovery site was first located in West Java with the death of 30 people, with actors as much as 3 , Diama 2 serving as abettors or brokers and the first person as the brain of the criminal trade in human organs or linking victims with buyers. Cases of organ trafficking crimes not previously discovered. Based on the results of research conducted by Riyadi and Bahaweres (2011), KPAI in 2010 has revealed cases of trafficking of human organs by as many as 14 cases of child victims. ${ }^{4}$

From a legal standpoint, transplantation of organs, tissues and cells of the body is seen as a noble endeavor in an effort to nourish and human welfare, although this is an act against the criminal law, namely the crime of persecution. But if the human organs are taken in the manner mode of sale of human organs, where it violates the provisions of human rights and can be included into the realm of the crime of trafficking in persons. In Appendix Health Minister Decree No. 518 / Menkes / PER / 2008 on Health Care for Participants PT Askes (Persero) and their family members in the Institute of Public

\footnotetext{
1. Aziz Shamsuddin, Special Crimes, Jakarta: Sinar Grafika, 2011, p. 33

2. M Agung Riyadi dan Rach Alida Bahaweres, Ketika Organ Tubuh Di Perdagangkan, 2012, p 35

${ }^{3 .}$. Agung Riyadi dan Rach Alida Bahaweres. "Ketika Organ Tubuh Diperdagangkan",http://groups.yahoo.com/group/BayiKita/messag/35143, 2011

${ }^{4}$ lbid.
} 
Health and Government Hospital, at point D explained that the cost of transplantation of organs for seventy-five million rupiah. The high cost to perform organ transplants trigger actions that are not well by elements who are not responsible to meet the request, so it is inevitable for the crime of trafficking in human organs originated from trafficking in persons (human trafficking), especially children and women.

Overcome these problems, in accordance with Act No.2 of 2002 on the Indonesian National Police, Act No.21 of 2007 on the Eradication of Trafficking in Persons, and Act No. 23 of 2002 on Child Protection, the police have the authority to do the investigation into the crime of trafficking in human organs to the implementation of the law in force in Indonesia, and in accordance with the role of the Police is mandated by the National Police regulation number 14 of 2012 on the Management of crime investigation. Based on the important role of the police in law enforcement, the investigation on the crime of trafficking in human organs.

Act No.21 of 2007 on the Eradication of Trafficking in Persons, Article 192 provides criminal sanctions for those who break them. The wording of Article 192 as follows: "Any person who knowingly trade in organs or tissue on whatever pretext, as referred to in Article 64 paragraph (3) in the criminal with a maximum imprisonment of ten (10) years and a maximum fine of Rp. 1,000,000,000.00 (one billion rupiah) ".

See coverage criminal cases serious human organ trafficking into the crime of trafficking in persons, so it can take its toll on the various parts of Indonesia, it would require national treatment patterns in accordance with the condition and very precise done by in particular law enforcement officials I Directorate General Crime Criminal Investigation Police. Based on this title right research to address these problems is of Investigation Crime of Trafficking in Human Organs In the Criminal Investigation Police (Police Report No. Case Study: Lp / 43 / I / 2016 / Bareskrim Date January 13, 2016).

The formulation of the problem in this research are: How execution investigation of criminal trafficking of human organs carried out by the Criminal Investigation Police?; What are the factors that affect the implementation of the investigation of criminal trafficking of human organs carried out by the Criminal Investigation Police?; Is the police efforts in tackling the trade in human organs and factors inhibiting the Police in tackling the trade in human organs?

\section{Discussion}

\subsection{Implementation Of The Investigation Of Criminal Trafficking Of Human Organs Carried Out By The Criminal Investigation Police}

Implementation of activities to address the issues of investigation crime of trafficking in human organs is done through catching, searches, seizure, securing evidence, securing the crime scene, crime scene processing, evaluation, verification and development of the case.

Activity implementation of the investigation by the Police Criminal Investigation done by providing guidance for the implementation of the investigation in accordance with the Regulation No. 14 Of 2012 on the Crime Investigation Management. Viewed criminal cases serious human organ trade in late 2015 and reported in early 2016 that 
successfully revealed by the Police Criminal Investigation investigators, it can be seen performed by referring to the Regulation No. 14 of 2012 on the Crime Management. With reference to the Regulation, it can be analyzed implementation measures investigations conducted by the Police Criminal Investigation investigators as follows:

- Plan

Planning activities undertaken by the Police Criminal Investigation investigators before an investigation is to make a warrant to carry out the task of investigation crime of trafficking in human organs. Having created a warrant task, the next step is to plan the investigation related to the division of tasks to personnel, create an implementation plan of investigation, and make supervision planning.

Schedule planning exploratory activities criminal offenses serious human organ trafficking conducted by the Criminal Investigation Police investigator based on the findings of research has been conducted in accordance with plans that exist, so that these planning activities to support the successful implementation of the Police Criminal Investigation investigators duty in disclosing the crime of trafficking in human organs.

The division of tasks and obligations of the members of the Criminal Investigation Police investigators are in accordance with the ability of personnel respectively, while based on research results further explained that the monitoring plan carried out by Kasubnit IV III Sub Dittipidum Criminal Investigation Police.

Based on the planning activities, it is known that the plans made are in accordance with the requirements at the time of the investigation, so it can support the successful implementation of the Police Criminal Investigation investigators duty in disclosing the crime of trafficking in human organs.

- Organizing

Organizing activities in the process of investigation conducted by the Criminal Investigation investigators police in the case is submitted to Kasubnit IV III Sub Dittipidum Criminal Investigation Police. By dividing the members that duty to conduct an investigation with the investigation evidence which applied triangle method.

Based on these findings, it can be seen that the organization carried out in conformity with the existing planning, so that it can support the successful implementation of tasks investigators Criminal Investigation Police in the disclosure of the crime of trafficking in human organs and minimize the operation failure investigation of a crime of trafficking in human organs such,

- Implementation

Conducting a Criminal by investigator that the investigation conducted in accordance with the Regulation's Police Number 14 Of 2012 concerning the Crime Investigation Management.

\subsection{Factors That Affect The Implementation Of The Investigation Of Criminal Trafficking Of Human Organs Carried Out By The Criminal Investigation Police}

Factors investigation of criminal offenses affecting the trade in human organs derived from:

- Constitution, 
- Investigator,

- Budget constraints,

- The selection of appropriate methods of investigation,

- The availability of facilities and infrastructure,

\subsection{Police Efforts In Tackling The Trade In Human Organs And Factors Inhibiting The Police In Tackling The Trade In Human Organs}

Police efforts to combat trafficking in organs, namely prevention, eradication and prevention of the crime of trafficking of human organs by running strategy repressive functions, namely in the form of punishment with the most severe penalties. Factors inhibiting factor is the legal, law enforcement, means infrastructures, society and culture

\section{Closing}

\subsection{Conclusion}

Based on the results of the above discussion can be summarized as follows:

- Implementation investigation of criminal trafficking of human organs carried out by the Criminal Investigation Police is the first instance be implemented. Implementation of this investigation in accordance with the Regulation no. 14 of 2012 on Management Investigations, where in the process the investigator did not experience any problems in the arrest of the perpetrators, because in the process of investigation the investigator obtain complete information from the victim as well as by using techniques evident triangle obtained further evidence used to catch the perpetrators.

- Factors that affect the implementation of the investigation of criminal trafficking of human organs carried out by the Police Criminal divided into two:

- The supporting factors derived from: The strength of law enforcement officers who have sufficient personnel and professional work of high; Community support in the disclosure of the crime of trafficking in human organs, as embodied in the form of providing information to investigators.

- Inhibiting factors derived from: Weak rule of law on the crime of trafficking in human organs; The availability of facilities and infrastructure is minimal; Cultural conditions of society, where people have a low awareness and knowledge about the crime of trafficking in human organs as well as the negative impact of the trade in human organs.

- Police efforts to combat trafficking in organs, namely prevention, eradication and prevention of the crime of trafficking of human organs by running strategy repressive functions, namely in the form of punishment with the most severe penalties. Factors inhibiting factor is the legal, law enforcement, means infrastructures, society and culture

\subsection{Suggestions}


Suggestions can be submitted related to the crime of trafficking in persons are:

- It is expected that the Government make strict controls associated with the crime of trafficking in human organs, so that the case of the crime of trafficking in human organs can be prevented

- It is expected that the Government, the Police and the Department of Health provides socialization and education related to the negative impact of the exploitation of human organs so that the people understand, comprehend and participate actively tackle the crime of trafficking in human organs

- It is expected that the Police made the MOU to the hospital, especially RSCM and other hospitals and clinics are used as a preliminary examination of victims around the location of recruiting victims of the crime of trafficking in human organs to immediately report any indication of TPPO and provide socialization on penalties against the perpetrators and institutions involved in the crime of trafficking in human organs.

- It is expected that the government may establish special rules for the law crime of trafficking in human organs in order that the crime of trafficking in human organs has strong legal force and binding.

\section{References}

\section{Books}

[1] M Agung Riyadi dan Rach Alida Bahaweres, Ketika Organ Tubuh Di Perdagangkan, 2012

[2] M. Agung Riyadi dan Rach Alida Bahaweres. "Ketika Organ Tubuh Diperdagangkan",http://groups.yahoo.com/group/BayiKita/messag/35143, 2011

[3] Syamsuddin Aziz, Tindak Pidana Khusus, Jakarta:Sinar Grafika

\section{Regulation Legislation}

[1] The Code of Criminal Procedure

[2] Book of the Criminal Justice Act

[3] Law of the State Police of the Republic of Indonesia, Fokusmedia 2010

[4] Act No. 23 of 2002 on the Protection of Children, Bandung

[5] The Regulation No. 14 Of 2012 concerning the Crime Investigation Management system. 